\title{
Fintech and Its Potential Impact on Islamic Banking and Finance Industry: A Case Study of Brunei Darussalam and Malaysia
}

\author{
Hassnian Ali \\ International Center for Research in Islamic Economics, ICRIE, Pakistan, Hassnian.icrie@mul.edu.pk \\ Rose Abdullah, Muhd Zaki Zaini \\ Universiti Islam Sultan Sharif Ali, Brunei Darussalam
}

Article History

Received: May 31, 2019 Revised: June 20, 2019 Accepted: July 8, 2019

\begin{abstract}
Fintech is growing at an exponential rate which leads to the emergence of innovative business models. Advanced technologies like Blockchain, internet of things (IOT's), artificial intelligence (Al), and robotics have become mature enough to create disruption in banking and finance industry both conventional and Islamic finance industry. Brunei Darussalam and Malaysia, both, offer wide range of Shari'a compliant services. The main purpose of this study is to investigate the potential impact of Fintech on the Islamic banking and finance industry in Brunei and Malaysia. Accordingly, this research deals with the qualitative method to accomplish and fulfill the research objectives. Content analysis and Semi-structured interview approach were employed throughout the research. The results clearly show that Fintech has great potential impact on both conventional and Islamic finance industry. This potential impact is in both ways i.e. positive and negative. And, the response and reaction of Islamic finance industry towards the emergence of Fintech and its potential impact seems very slow as compared to their conventional counterparts. This study has indicated important points which include the necessity for the Islamic financial institution to cope with the growth of Fintech.
\end{abstract}

Keywords: Fintech, Potential Impact, Islamic banking and finance, Brunei Darussalam, Malaysia JEL Classification: 014, 032, 033, 057, Y10

@ IJIEF 2019 published by Universitas Muhammadiyah Yogyakarta, Indonesia All rights reserved

DOI:

https://doi.org/10.18196/ijief.2116
Web:

http://journal.umy.ac.id/index.php/ijief/article/view/6364

Citation:

Ali, H. Abdullah, R. \& Zaini, M. Z. (2019). Fintech and Its Potential Impact on Islamic Banking and Finance Industry: A Case Study of Brunei Darussalam and Malaysia. International Journal of Islamic Economics and Finance (IJIEF), 1(2),73-108. Doi: https://doi.org/10.18196/ijief.2116. 
Ali, Abdullah, \& Zaini | Fintech and Its Potential Impact on Islamic Banking and Finance Industry: A Case Study of Brunei Darussalam and Malaysia

\section{Introduction}

The world faces original problems and challenges. It is the first time; the whole society is on the verge or exceeding critical globally ecological limits. This situation leads to the frustration for researchers, economists, and technologist because it must create some 1.5 billion new livelihoods by 2050 against a backdrop of population growth and increasingly speedy technological changes. The history has witnessed three stages of the industrial revolution; the First Industrial Revolution used steam power and water to mechanize and increase production. The Second revolution used electric power to create a bulk production. The Third used advanced electronics and information technology to make the production automate. Now, we are in fourth Industrial Revolution which is based on the third, the digital revolution that has been started and occurring since the middle of the last century. It is typified by a fusion of technologies that is blurring the lines between the economical, physical, biological, and digital spheres (World Economic Forum, 2016).

In this present era, it is not easy to imagine a world without the internet or mobile devices. They have become core elements of our lifestyle and have brought a high degree of disruption to virtually every area of business. The financial services (FS) industry is no exception; the digital revolution is transforming the way customers access financial products and services. Although the sector has experienced a degree of change in past years, but the constant penetration of technology-driven applications in nearly each and every segment of FS is something new.

Amidst of the digital revolution 4.0, a new industry called "Fintech industry" emerged and exploded around the globe. Fintech is becoming a big disruptor of existing banking and finance industry due to the provision of same but more innovative financial services as those provided in traditional banking and finance industry except with lower fee costs and with high margins. Islamic banking and finance industry also subject to immense pressure especially due to the fee costs in the Islamic banks is higher than conventional banks. Fintech has circled the whole finance space.

Fintech is growing at an exponential rate which leads to the emergence of innovative business models. In 2017, global Fintech financing hit a new record of $\$ 16.6$ billion as compare to 2016 (it was $\$ 13.3$ billion) (CB Insights, 2018).During 2018, fintech venture capital backed fundingwas dominated by Asia with $\$ 22.65$ billion across 563 deals. US followed by Asia hit \$11.89 billion across 659 deals. Europe hit $\$ 3.53$ billion across 363 deals (CB Insights, 2019). 
Ali, Abdullah, \& Zaini | Fintech and Its Potential Impact on Islamic Banking and Finance Industry: A Case Study of Brunei Darussalam and Malaysia

Adoption of digitalization is on the high in Islamic finance industry, with conspicuously GCC countries in which Bahrain is trying to become a leader through a partnership of Bahrain Islamic Bank with Bahrain Fintech Bay, and the establishment of the first shariah-compliant digital bank. Investment platforms for potential investors are also proportionally developed mostly by using Blockchain, while venture capital and crowdfunding are put into place to gain the necessary funds. The Islamic finance industry was estimated to be worth US\$2.4 trillion in 2017 and forecast to grow by 7.7 percent CAGR to reach US\$3.8 trillion by 2023.

Fintech is very new industry and it becomes more nascent when it combines with Islamic finance industry. The recent studies conducted on Fintech (Biancone, Secinaro, \& Kamal, 2019; Lacasse, Lambert, \& Khan, 2017; Laldin\&Furqani, 2019; Todorof, 2018)with the combination of Islamic finance do not cover the topic holistically and there is no study available especially based on primary data. These studies specifically elucidate one of segments of Fintech such as crowdfunding, use of blockchain etc. This is justified due to newness of the Fintech and its adoption in Islamic finance industry is also at very initial stage. Thus, there is enormous research gap existed in this field. Researchers tried to explore the potential impact of this emerging industry on Islamic Finance industry in two countries i.e. Brunei Darussalam and Malaysia. As, it is no doubt that Brunei Darussalam and Malaysia have well organized and established Islamic financial services industry. But the emergence and growth of the Fintech and its potential impact on Islamic financial industry cannot be overlooked and neglected. So, this study examines the different aspects of Fintech and its potential impact on Islamic banking and finance sector in Brunei Darussalam and Malaysia. Everyone is now expecting different results and has different assumptions about the impact of Fintech on Islamic banking and finance. A review of the present literature does not provide a clear-cut answer to this question. The work, thus, attempts to fill this gap in the literature on the potential impact of Fintech on Islamic banking and finance in Brunei Darussalam and Malaysia by using scientific research methodology and investigation tools.

\section{Literature Review on Fintech in Islamic Finance Industry}

\section{Theory}

The Interconnection between finance and technology has a long history. It is necessary to distinguish three major eras of Fintech evolution. From around 1866 to 1987, a period which is named as Fintech 1.0 during this period the financial services industry was interlinked with technology, but as an analog industry and use of telegraphy. By 1987 the financial services industry and 
Ali, Abdullah, \& Zaini | Fintech and Its Potential Impact on Islamic Banking and Finance Industry: A Case Study of Brunei Darussalam and Malaysia

technology connection changed from analogy to digitalization. This period, which is characterized as Fintech 2.0, continued until 2008. During Fintech 2.0, Fintech was dominated primarily by the regulated traditional financial services industry that used technology to provide financial products and services. However, since 2008 which has witnessed a big financial crisis leads to a new paradigm shift for a new Fintech period which is called as Fintech 3.0. During this era of post-crisis technology industry has also become advanced and new digital devices including smartphones, smart wearables, heath tech instruments, 3D printers, smart homes have been introduced. New start-ups and established technology companies have begun to deliver financial products and services directly to businesses and the general public. Fintech 3.0 emerged as a reaction to the financial crisis in the West, but in Asia and Africa recent Fintech advancements have been primarily prompted by the pursuit of economic development. This era in these two regions is named as Fintech 3.5. Thought the Fintech is not a new concept; however, it is only since 2014 that the sector has attracted the great attention of regulators, industry participants and consumers alike. Islamic finance industry with no more exception also tapped into Fintech industry. With the combination of Islamic finance and Fintech, Islamic Fintech has emerged as Islamic version of Fintech. There are ninety-three Islamic Fintech companies in different jurisdictions predominantly leveraging peer-to-peer technology to disrupt personal and business finance and eliminate subsidiary service providers.The sixty-six Islamic Fintech companies are concerned and focusing on making business and consumer finance more easy, cheap and accessible. There are fourteen Islamic Fintech companies deploying Blockchain technology in their solutions (Dinarstandards, 2018).

On the basis of this evolutionary analysis, it is possible to develop a comprehensive typology for the Fintech industry. Fintech today comprises five major areas: (1) finance and investment, (2) Financial operations and risk management, (3) payments and infrastructure, (4) data security and monetization, and (5) customer interface. The payments industry today is in a state of constant change, with several economic, technological, and demographic factors at cutting edge across the length and breadth of the value chain. The industry is observing rapid development in innovations across the value chain, thus making it more splintered (Capgemini, 2016).

$\mathrm{P} 2 \mathrm{P}$ lending is considered an alternative to banking lending through an online platform that facilitates the lending of funds from one peer to other peer or peers. The P2P business model is different from that of traditional banks. According to Morgan Stanley, it is expected that marketplace lending will attain $\$ 290$ billion by 2020, averaging 51\% growth per year. But in the more optimistic scenario, this sector is seen exceeding $\$ 490$ billion by 2020 (Coraggio, 2017).Meanwhile, the crowdfunding industry is doubling or more,

IJIEF: International Journal of Islamic Economics and Finance, 2(1), 73-108 | 76 
Ali, Abdullah, \& Zaini | Fintech and Its Potential Impact on Islamic Banking and Finance Industry: A Case Study of Brunei Darussalam and Malaysia

every year, and is spread across several types of funding models including rewards, donation, equity, and debt/lending. The analysts forecast the global Crowdfunding market to grow at a CAGR of $26.87 \%$ during the period 2016 2020 (Research and Markets, 2016). InsurTech is also one of the segments of Fintech addressing existing insurance opportunities, potential and challenges. Insurers are introducing lifestyle apps that give additional consumer value on a continuing and constant basis.

The supporting technologies which are the core of Fintech industry include Blockchain, big data, robo advisory and artificial intelligence. The world Economic Forum (WEF) has given the six important findings related to the implications of blockchain on the future financial services industry. This forum suggested that this technology has great potential to drive efficiency and simplicity by reshaping the infrastructure and process within financial industry. WEF concluded that blockchain technology is not a panacea, but it is one of the new emerging technologies that will establish the financial infrastructure for a new generation (World Economic Forum, 2016). A research firm International Data Corp (IDC) defines Big data as "the intelligent economy produces a constant stream of data that is being monitored and analyzed. Social interactions, mobile devices, facilities, equipment, R\&D, simulations, and physical infrastructure all contribute to the flow. In aggregate, this is what is called Big Data" (International Data Corp. (IDC), 2012). The volume of data is growing exponentially, and it is expected that by 2020 there will be more than 16 zettabytes (16 Trillion GB) of useful data (Turner, Gantz, Reinsel \& Minton, 2014). There are several ways for financial services industry to achieve business advantages by mining and analyzing data. These include enhanced detection of fraud, retail customer service, and improvement of operational efficiencies. Big data also can be used to identify exposure in real time across a range of sophisticated financial instruments like derivatives. Predictive analysis of both internal and external data results in good, proactive management of a wide range of problems from credit and operational risk (e.g. fraud and reputational risk) to customer loyalty and profitability. Robo-advisors also quickly attained market traction, overseeing $\$ 19$ billion by the end of 2014. According to two research firms, KPMG and CGI forecast the number will hitting to $\$ 2$ trillion in assets by 2020 (Patpatia\& Association and CGI, 2016).KPMG's survey forecasts that $75 \%$ of survey's respondents are interested in Robo-advisor services (KPMG, 2016). Artificial intelligence (AI) in this digital era has become a hot topic with regards to the advantages that it can bring to the financial services industry. Al can help banks in their anti-money laundering or employee misconduct detection efforts by replacing costly functions that are currently done manually by humans (Arslanian, 2016). 
Ali, Abdullah, \& Zaini | Fintech and Its Potential Impact on Islamic Banking and Finance Industry: A Case Study of Brunei Darussalam and Malaysia

\section{Previous Studies}

Researchers in the field of Islamic finance have just started paying attention to the area of Fintech. It is important and noteworthy to highlight and admit that an attempt to collect a body of literature on Fintech related to Islamic finance, will unable to get a single scholarly writing. There were plenty of studies available on Islamic Crowdfunding but those studies also missing the other segments, which are numerous, of this broad industry of Fintech. See Alonso (2015); Khan (2015); Lutfi \& Ismail (2016); Marzban, Asutay \& Boseli (2014); Ng, Mirakhor \& Ibrahim (2015); Taha \& Macias (2014); Torabi (2017); and Wahjono \& Marina (2017).

With the acceptance of that Islamic finance researchers are at infancy stage regarding research on this particular area of Fintech with the link of Islamic banking and finance. There are some scholarly studies with regards to the practice of Fintech within Islamic financial institutions have started being published in second half of 2017. Finocracy \& Mirakhor (2017)provide a view on how Fintech can accelerate the adoption of risk sharing Islamic finance and focused on Blockchain technology and its potential in the enhancement of adoption of risk sharing finance.

Another study done by Lacasse, Lambert, \& Khan (2017)focused on Blockchain technology and they provide the view on the possibility of using Blockchain technology for the assurance of Shariah compliance in Islamic finance industry. These both studies give a general overview of Fintech and then concentrate on Blockchain technology and its potential in Islamic finance industry.

Malaysian International Islamic Financial Center (2016) published a report on financial technology in Islamic Finance and explored that with the progress of Islamic banking and finance, technology has become a key enabler for future financial services and business. MIFC report also highlighted one of the innovative products of Islamic finance which is currently launched in Malaysia i.e. an Investment Account Platform (IAP). This platform was developed by the owned unit of Raeed, IAP Integrated Sdn. Bhd. which comprised a consortium of various Islamic financial institutions. Through this platform will provide the investors with direct access to the new investment opportunities and businesses as well as Islamic banks with many innovative sources of funding. Two piece of studies written by Lajis (2017), she opined in her studies that Fintech can be proved as a game changer for Islamic finance industry especially in the promotion of risk sharing Islamic finance. Because of big hype of Bitcoin and cryptocurrencies in 2017 we have found some studies on cryptocurrencies especially bitcoin and their shariah appraisal (Adam, n.d.; Bergstra, 2015; Evans, 2015; Lim \& Masih, 2017; Nordin, Hassan, \& Nor, 2017; Nurhisam, 2017; Tayel \& Sganga, 2015; Zubaidi 
Ali, Abdullah, \& Zaini | Fintech and Its Potential Impact on Islamic Banking and Finance Industry: A Case Study of Brunei Darussalam and Malaysia

\& Abdullah, 2017). These studies discuss the topic with the lens of shariah legitimacy of bitcoin and cryptocurrencies. And still there is great confliction have been found among scholars regarding this issue. Apart from these scholarly research writing related to different segments (crowdfunding, Blockchain and Bitcoin) of Fintech with the combination of Islamic commercial law and Islamic finance, we have seen some general articles on different blog sites, social sites (Linkedln), magazines and newspapers from different authors like (Abdullah, 2017; Hasan, 2017; Mohamed, 2017; Munshi, 2017). These writers discuss different topics, like smart contracts in Islamic finance, Fintech opportunity or threat for Islamic finance, Fintech for Islamic finance, Fintech is a game changer for Islamic finance etc.

\section{Research Methodology}

\section{Data}

The primary data collection perpetrated deploying interviews. The interviews of incumbents of Islamic banks and takāful companies are conducted for this purpose. Then the collected data is summarized and analyzed through various stages including the organization of data, familiarization, coding, and developing themes, etc. The majority of the selected persons from both countries are of manager rank in their organizations. They are linked with innovation, technology, research and development departments in their respective organizations. This lead to the validity and reliability of their opinions on any topic or issue. By doing interviews, it is possible to get extensive information and to deepen the understanding of the subject of the study. The interview questions in this research consist of semi-structured questions. The questionnaire for interview is divided into three parts. First part covers nine questions which are constructed to accomplish the second research objective and to answer the second research question. The second part of the questionnaire for interview encompasses three questions which are constructed to fulfil the third research objective and to answer the third research objective. The third part is about the demographic details of the respondents.

There were total nine interviews conducted in both countries, four from Brunei and five from Malaysia.

To cope with the criteria of research sample and to attain the targeted number of Malaysian Islamic banks, researcher selected annual reports of four Malaysian Islamic banks. So, in this research study researcher took six Malaysian Islamic banks and three takaful companies as a sample. These reports are used as content analysis. The annual reports of selected Islamic 
Ali, Abdullah, \& Zaini | Fintech and Its Potential Impact on Islamic Banking and Finance Industry: A Case Study of Brunei Darussalam and Malaysia

banks of Malaysia were downloaded from their organizations' sites. These reports are used for the purpose of content analysis through NVivo 11. After making analysis, findings are explored to show what has been observed and concluded through the whole process of investigation and finally, recommendations are provided.

\section{Method and Model}

This study is based on the qualitative research method viz a viz exploratory research design. The qualitative research method also involves interviews and texture or content analysis that permits the researcher to use these tools in accomplishing the research objectives. Researcher applied this method and used these tools to explore the potential impact of Fintech development on Islamic banking in Brunei Darussalam and Malaysia and secondly to sort out the strategies for Islamic banking industry regarding Fintech in Brunei Darussalam and Malaysia. This exploratory research design with the interviews is used to identify and to know the opinion and perception of experts and personnel of the industry on a current issue. In this research study the researcher conducted interviews and ask the industry people about the potential impact of Fintech on Islamic banking in Brunei Darussalam and Malaysia and also about the strategy that should be adopted by Islamic banking regarding Fintech in both countries. The NVivo 11, Computer-Assisted Qualitative Data Analysis Software (CAQDAS) is used in this research to analyze and interpret the data. To make comprehensive analysis of the data, the interviews are coded by NVivo.

Content analysis is used with both qualitative and quantitative data in an inductive and deductive ways. But, the common use of content analysis is with qualitative data (Elo \& Kyngäs, 2008). There are three approaches in content analysis used to explain the meaning from the selected text data. These three are conventional, directed and Summative approaches. Researcher adopted summative approach in this research. As this approach involves counting of key term or words from the selected documents followed by the explanation. Researcher applied this approach to count the word Fintech in the selected documents and then compare the coverage of that term among selected reports. For explanation of the content related to Fintech in the selected reports, researcher also extracted all the content related to term Fintech from the reports, NVivo 11 is used to do summative content analysis.

Firstly, researcher edited the content of the interviews conducted from the targeted interviewees. The editing of the interviews in a special format is essential before starting to analyze them in NVivo. After editing the 
Ali, Abdullah, \& Zaini | Fintech and Its Potential Impact on Islamic Banking and Finance Industry: A Case Study of Brunei Darussalam and Malaysia

interviews, the researcher uploaded Microsoft office word files of interviews into the NVivo 11 software. These files considered as sources in NVivo 11. Into the NVivo software, researcher form the main nodes and then child nodes of each question. This provides the most relevant statements of interviewees regarding questions. Researcher also used the suggestions of (Maxwell, 2012)in constructing main and child nodes and in doing coding. The main node shows the theme of the question and child nodes show the responses of the interviewees regarding the question. Then, finally, a project map for each question is drawn to show the responses of all the interviewees regarding each question. The project summary report that covers the name of nodes and child nodes with the number of sources and also the references related to the nodes, time of creation and name of the creator. A sources summary report also produced by the researcher through NVivo 11 which shows the total number of nodes including the main nodes also called anchor nodes and child nodes, and the number of project maps which are created by the researcher (See Appendix A \& B).

In doing content analysis of the selected reports, NVivo 11 is also used. The reports in pdf form were uploaded into the software and the search query of the word Fintech was processed. The table of coverage of the word Fintech is also constructed. Then, the most relevant paragraphs which discuss and cover the term Fintech were separated and extracted from all the reports and a figure was exported as an evidence.

The model which is developed as given in the following figure is authors' own designed model as this model is generally used in qualitative studies. It provides flexibility to the research while exploring a new and emerging phenomenon or industry. 
Ali, Abdullah, \& Zaini | Fintech and Its Potential Impact on Islamic Banking and Finance Industry: A Case Study of Brunei Darussalam and Malaysia

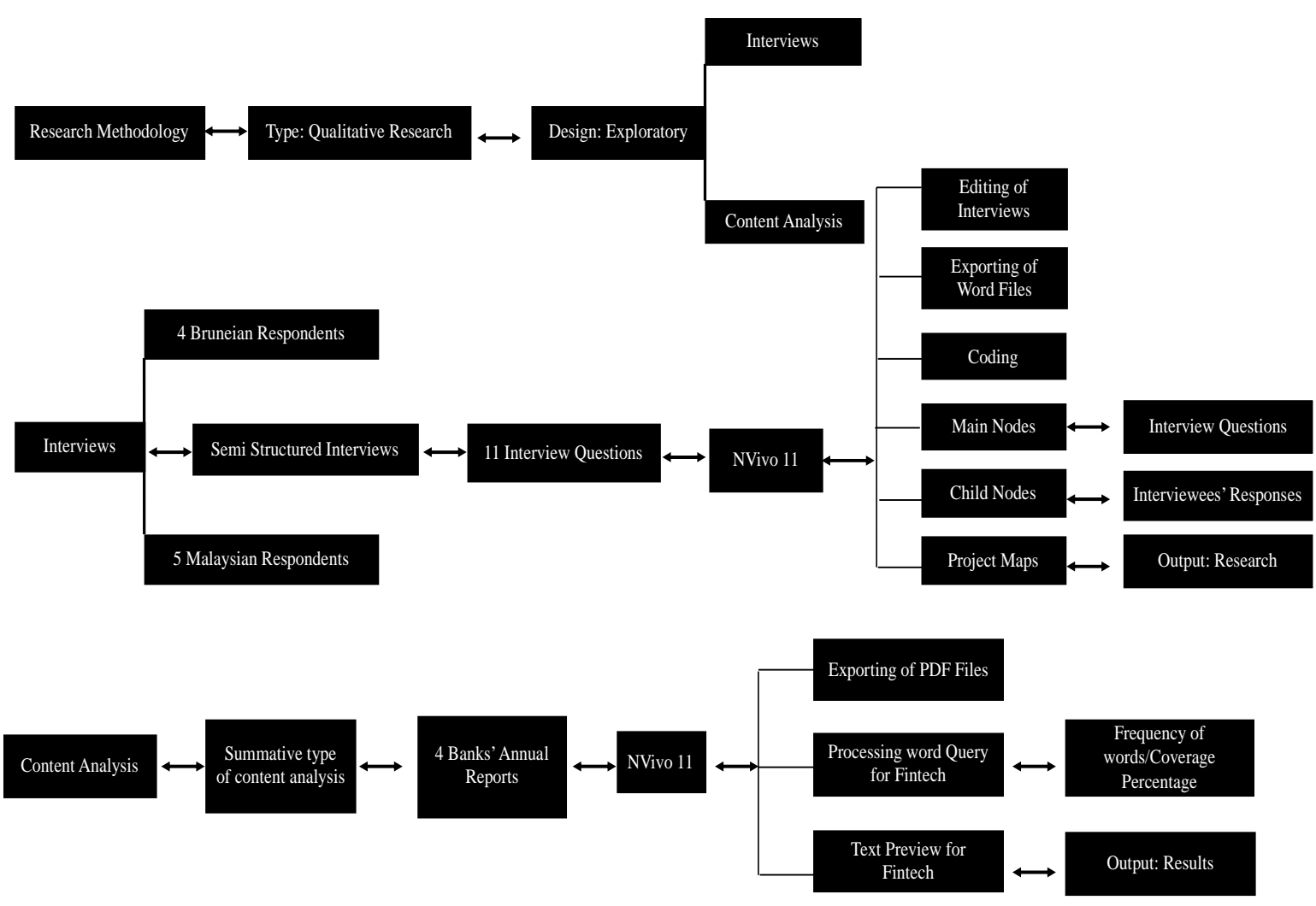

Figure 1. Research Methodology

\section{Results and Discussions}

\section{Results}

\section{Demographic Details of Interviewees}

Following table 1.0 shows the detail of demographics of all the interviewees from both countries Brunei Darussalam and Malaysia. B1, B2, B3 and B4 represent interviewees from Brunei Darussalam (See Appendix A for results). M1, M2, M3, M4, and M5 represent interviewees from Malaysia (See Appendix B for results). 
Ali, Abdullah, \& Zaini | Fintech and Its Potential Impact on Islamic Banking and Finance Industry: A Case Study of Brunei Darussalam and Malaysia

Table 1. Demographic Details of Interviewees

\begin{tabular}{lllllll}
\hline No. & Gender & Age & Nationality & Education & Post & Industry \\
\hline B1 & Male & 36 & Bruneian & Bachelor & Manager & Banking \\
B2 & Male & 47 & Bruneian & MBA & Manager & Banking \\
B3 & Male & 45 & Bruneian & $\begin{array}{l}\text { Higher National } \\
\text { Diploma }\end{array}$ & Manager & Takaful \\
& & & & Bachelor Degree & Deputy General & Takaful/ \\
B4 & Male & 38 & Bruneian & Banager & Insurance \\
& & & & & Manager & Banking \\
M1 & Female & 33 & Malaysian & Master & HOD Innovation & Banking \\
M2 & Male & 45 & Malaysian & Master & Manager & Takaful \\
M3 & Male & 34 & Malaysian & Master & Manager & Takaful \\
M4 & Male & 35 & Malaysian & Master & Manager & Insurance/Takaful \\
M5 & Male & 37 & Malaysian & Bachelor & &
\end{tabular}

The above Table 1 shows the demographic details of all the interviewees of both countries. All of the Bruneian and Malaysian respondents were male except one Malaysian female respondent. This table also highlights that the respondents are having good experience in financial industries because most of the respondents having age between 35 to 45 years. This also shows that all of the respondents are well educated as majority has Master level of education. One of important things is that majority of the respondents are of manager rank in their corresponding organizations. This means their opinion on an issue has great value in making some conclusion about an issue. This set of respondents is very fit for qualitative research within the exploratory research design. The opinion and perception of the experts helps the research to get the answer of the research questions and also to attain research objectives.

\section{NVlvo 11 Results on Interviews' data and its analysis}

Potential Impact of Fintech on Islamic banking in Brunei Darussalam and Malaysia. This section encompasses eight interview questions which deal and answer the first research question.

\section{a. Definition of Fintech}

Here is the attempt to investigate the definitions and understanding of all the interviewees through the lens of available definitions of Fintech present in the literature.

The results show that the responses of 4 respondents from Brunei Darussalam with regards to the definition of Fintech. According to one respondent $\mathrm{B} 1$ and the two respondents $\mathrm{B} 3$ and $\mathrm{B} 4$ explained that Fintech is 
Ali, Abdullah, \& Zaini | Fintech and Its Potential Impact on Islamic Banking and Finance Industry: A Case Study of Brunei Darussalam and Malaysia

the combination of finance and technology and B1 also added that Fintech is just a tool not any product or a model. And the fourth respondent B2 said Fintech is all about automation and it can be defined as "automated interactions with customers".

The findings indicate that the responses of 5 respondents from Malaysia regarding definition of Fintech. Two respondents $\mathrm{M} 1$ and $\mathrm{M} 2$ mentioned that Fintech is the emerging financial services sector that deploys the technology. On the other side the two respondents M3 and M4 thought that Fintech is the redefining of banking and takaful industry. They also added that Fintech is the use of technology that gives customers access to banking. And the fifth respondent M5 was unable to explain this term. The definitions of Fintech provided by the respondents from Brunei do not cover the holistic or whole concept of Fintech. They just define the epistemological meaning like Fintech is the combination of Finance and technology and it is merely a tool. On the other hand, definitions provided by the Malaysian respondents do cover the main concept of Fintech like as two respondents from Malaysia $\mathrm{M} 1$ and $\mathrm{M} 2$ mentioned that Fintech is the emerging financial services sector that deploys the technology. This definition said Fintech is an emerging financial sector, this point is mentioned in the definition of Fintech provided by (Schueffel, 2016). One of the Malaysian respondent said Fintech is the redefining of banking takaful industry. This main point is also highlighted in a number of studies (Dhar \& Stein, 2017;Broby \& Karkkainen, 2016). Fintech refers to "innovative financial services or products delivered via technology and with advancements in technology (such as mobile and internet) coupled with their global widespread adoption, consumers expectations are changing"(Kuo Chuen, Teo, \& others, 2015).One of the common point mentioned in the definitions of both countries is that Fintech provides access of banking to the customer through automated channels. Finally, all the points can be summarized in one definition that "Fintech is a new and emerging financial services industry which is harnessing advanced technology to provide innovative and traditional financial services and products to the customers through multi and automated channels".

b. Potential Disruption Areas of Islamic Banking and Finance Industry

The results exhibitthat the responses of respondents regarding the disruption areas of Islamic finance industry which have been precipitated by the development of Fintech. All four respondents answered very short as two respondents B2 and B3 gave similar answer. They said all segments of Islamic finance industry may be disrupted. But another respondent B1 claimed that there is not any disruption due to Fintech for any segment of 
Ali, Abdullah, \& Zaini | Fintech and Its Potential Impact on Islamic Banking and Finance Industry: A Case Study of Brunei Darussalam and Malaysia

Islamic finance industry in Brunei Darussalam. And the fourth respondent B4 opined that Islamic finance industry is very slow to respond Fintech.

The results show that two respondents, M4 and M5 opined that all of the Islamic banks and takaful companies still exploring and observing the emergence Fintech. Remaining three respondents, M1, M2 and M3 think that due to emergence of Fintech there is the need to re-assess traditional way of conducting businesses and re-engineering and provision of innovative offerings to the customers.

It is cleared from these answers that all the interviewees are unable to give the name of areas of Islamic finance industry, like payments, takaful, consumer banking etc. which have potential impact by the Fintech. On the other hand, these results show that some of the respondents think that the whole Islamic finance industry may disrupt due to Fintech. The same question with different words is also covered in different surveys conducted and published by numerous forums and research firms including PWC, Capgemini, McKinsey \& Co. and CFA institute etc.

In a survey conducted by (PwC, 2016b)from only Malaysian financial institutions and Fintech companies, it has been shown that both Malaysian traditional financial Institutions and Fintech companies thought alike when they were asked about three top areas of financial services that are prime for disruption.

In a survey conducted and published by (CFA Institute, 2016), the question was asked that what are the top areas of financial services can be disrupted due to automated financial advice tools (robo advisors). 54\% of the survey's respondents opined asset management followed by banking (16\%), securities (12\%), insurance (8\%), financial advisors and wealth management (7\%) and $3 \%$ chosen none of the above option.

c. Fintechs will take Customers from Islamic Financial Institution

The results highlight that the opinions of respondents about a statement that Fintech will take customers from Islamic financial institutions due to providing better customers' experience. Three respondents, B2, B3 and B4 opined that Fintech will take customers from IFI's and B2 and B4 also said that this will happen if IFI's keep away from embracing Fintech or innovative models and technological adaptation. But, B1 said there is no chance for Fintech to take customers from IFI's.

The findings show that 4 out of 5 respondents are agreed with the statement that Fintech will take customers from Islamic Financial institutions. M4 also mentioned that this can be happened if the IFI's will not fulfil the needs of the millennial generation. M3 also added that Fintech is in 
Ali, Abdullah, \& Zaini | Fintech and Its Potential Impact on Islamic Banking and Finance Industry: A Case Study of Brunei Darussalam and Malaysia

line with the digital shift. Only one respondent M1 disagreed with the statement but she also clearly opined that IFI's should embrace technological transformation on leveraging.

From these results it is clear that majority of the respondents are agreed on the statement that "Fintech innovations offer end customers a noticeably better value proposition, in terms of ease of use, cost, the speed of service and integration with social media" which lead to their agreement with a hypothetical view that Fintech will take customers from the IFI's. Respondents also explain and give the reason of this agreement that Fintech is in line with the digital shift. And they further added that IFIs will lose the customers if they will not fulfil the needs and will not embrace the Fintech. These results are strong supported by large number of studies and survey reports.

d. Potential of Blockchain and Smart Contracts in Islamic Finance Industry

The findingsexhibit that the opinions about deploying technologies like blockchain, smart contracts and their potential in Islamic finance industry. 3 out of 4 respondents from Brunei Darussalam opined that these technologies have potential mean these can be used in Islamic finance industry to bring efficiency in operations and products as well. Only one respondent which is B1, he said "I don't believe on any kind of blockchain". Majority of respondents highlighted that there is the challenge of shariah compliance that should be tackled when deploying these technologies.

The results exhibit that M4 and M5 elucidated that in Malaysia they have not seen any development or adoption of blockchain. M4 also added that smart contracts have big potential in Islamic banking and finance. The respondents from M1, M2 and M3 opined that there is more control (law and preventive solutions) and in-depth studies needed to be conducted to understand the potential opportunities that offer blockchain. M3 also added that blockchain is good in recording transactions hence facilitating more secure online transactions.

These results show that majority of the respondents opined that the Blockchain and smart contracts have potential in Islamic finance industry. But the respondents also mention that there is still need for understanding of this technology and the challenge of shariah compliance must be addressed. These results are also supported and similar to different reports and studies (Veronika, 2016)Mohamed, 2016).According to Accenture report, blockchain is one of the most talked about topic in the present financial services industry. 90\% banks' executives are interested in blockchain and currently their banks are exploring the use of blockchain in the payments' industry. Moreover,

IJIEF: International Journal of Islamic Economics and Finance, 2(1), 73-108 | 86 
Ali, Abdullah, \& Zaini | Fintech and Its Potential Impact on Islamic Banking and Finance Industry: A Case Study of Brunei Darussalam and Malaysia

this report also highlights the benefits of using this technology in payment industry these are lower frictionless cost, shorter settlement time, reduce errors, new revenue opportunity, and lower administrative cost(Accenture, 2016a).In another report published by (PwC, 2016a) explains that a majority of respondents (56\%) recognize the importance of blockchain and smart contracts, $57 \%$ say they are not sure or unlikely to respond to this trend. As the one respondent B1 from Brunei said he does not believe on any kind of blockchain. This may be explained by the very low level of familiarity with this innovative technology as $83 \%$ of respondents are at best "moderately" familiar with it and only very few consider themselves to be experts (PwC, 2016a).The point about legal and compliance is also discussed in numerous studies. (PwC, 2017,IOSCO, 2017) elucidate that for smart contracts to take root, legal finality must be clear and the smart contract must be enforceable in law.

e. Potential of Artificial Intelligence, Big data, loT and Robo Advisors in Islamic Finance Industry

The findingsshow that all the respondents think that the technologies, like Artificial Intelligence (AI), big data, IOT, and robo advisors have big potential in Islamic finance industry. B3 and B4 also added that there are some challenges and issues as well as risk of data sharing and privacy in usage of Big data.

The results reveal that $\mathrm{M} 2, \mathrm{M} 3$ and $\mathrm{M} 4$ clearly opined that ' $Y e s$ ' the adoption of cloud computing Islamic finance industry can reduce their IT cost. M1 and M5 neither said 'Yes' nor 'No'. And M1, M4 and M5 also added that data security, cyber-attacks and legal risks are also involved. These results clarify that majority of the respondents from both countries especially, all the respondents from Brunei opined that they are all think that the technologies, like Artificial Intelligence Al, big data, loT, and robo advisors have big potential in Islamic finance industry. And some of the respondents also highlight that before adoption of these technologies in the industry data security, cyber-attacks and legal risk must be discussed. The same results have been found when asked and discussed this point by conventional counterparts in different reports and studies.

White House' report shows that by using big data educational opportunities can be increased. Data and algorithms can potentially help law enforcement become more effective, transparent, and efficient(The White House, 2016).Grouping Al, machine learning, big data and blockchain together as a "cognitive business and technology model", Rometty said "there is a moment of opportunity if you want to catch it", with these technologies offering and providing the potential to reduce costs and improve opportunity spotting and compliance. The winners, according to her, will be 
Ali, Abdullah, \& Zaini | Fintech and Its Potential Impact on Islamic Banking and Finance Industry: A Case Study of Brunei Darussalam and Malaysia

those businesses that are able to deploy these technologies effectively. "You will need some new technology to deal with all of the data that is out there in order to gain insights, comply and operate efficiently" (Accenture, 2016c).

\section{f. Cloud Computing Adoption}

The results show that all the respondents unanimously opined that cloud computing has potential and its adoption is a good option for IFI's. B1 and B4 also added that the decision of this adoption depends upon the institution's policy and resources as well. Three respondents except B4, highlighted that there are some risks and challenges involve in the adoption of cloud computing for IFI's. Like B1 said that legacy system of banks also acts as a problem and challenge as there are multi tiering legacy systems functioned in banks. So, it is not easy to embrace innovation and especially technological innovation like cloud computing. According to B3 there is the scalability. It means there is the limit of data which we can control and store in the form of clouds and also with the time limit. So, what will happen if the company finished the agreement with the bank. Finally, B2 opined that there is the risk of cyber security which should be managed before adoption.

The findingsshow that M2, M3 and M4 clearly opined that yes, the adoption of cloud computing Islamic finance industry can reduce their IT cost. M4 and M5 neither said yes nor No. And M1, M4 and M5 also added that data security, cyber-attacks and legal risks are also involved. According to a report provided by a research firm "Peak 10" the financial sector does show greater hesitation to using the cloud than other industries, but some specific aspects of financial IT environments have already been migrated, while others are in the works. For example, software as a service (SaaS) usage is on the rise, showing that the level of comfort and frequency of cloud adoption are increasing in the financial sector for both insurance companies and banks. $48 \%$ of banks are using SaaS for administrative functions, $24 \%$ of banks are using SaaS for mobility, and while $15 \%$ of insurance companies are using in different operations. This report also highlighted some risks in the adoption of cloud computing as $58 \%$ of respondents reported loss of control over data as the top cloud risk and fear (Financial Services Cloud Adoption, 2017).

\section{g. Promotion of Financial Inclusion through Fintech}

The results enumerate the opinions of respondents about the promotion of financial inclusion by using Fintech through IFI's. All the respondents agreed with the statement that IFI's can promote financial inclusion by providing financial services to underbanked or unbanked people via Fintech. Moreover, B2 and B4 also added that mobile technology can help a lot for financial inclusion.

IJIEF: International Journal of Islamic Economics and Finance, 2(1), 73-108 | 88 
Ali, Abdullah, \& Zaini | Fintech and Its Potential Impact on Islamic Banking and Finance Industry: A Case Study of Brunei Darussalam and Malaysia

The results depict that all the Malaysian respondents agreed with the statement that Islamic Financial Institutions (IFI's) can promote financial inclusion by providing financial services to underbanked or unbanked people via Fintech. M3 added that Fintech has allowed this by providing innovative solutions as a new touchpoint for customers. M2 thinks that Fintech provide solutions but it would not solve underlying cause of this problem. Moreover, the respondents focused on mobile technology which they opined that it can help a lot to promote financial inclusion. According to Mobile Payments and Fraud Survey, $60 \%$ of respondents from all types of organizations as well as merchants considered a mobile strategy to be "Very Important" to promote financial inclusion (Kount, 2016). There are numerous studies which support these results. Islamic Financial Services Board, IFSB, (2017)in his latest report on Islamic finance industry make a valuable addition and discussed Fintech and shariah compatibility and application to Islamic finance industry, regulatory issues and financial inclusion. Report also claims that Islamic Fintech can grow and develop rapidly in the jurisdictions where Islamic banking has attained systematic and reasonable importance.

h. Fintech Segments which can grow in Brunei Darussalam and Malaysia

The results show that three respondents B2, B3 and B4 opined that the Fintechs that will provide banking services can grow in Brunei. B2 add payment sector as well. But, B1 didn't give any clear answer of this question. B1 just mentioned that his organization is providing all the banking services to their customers and working very well.

The findings show that $\mathrm{M} 1, \mathrm{M} 2$ and $\mathrm{M} 4$ opined that Payments is the sector in which Fintech can grow repidly in Malaysia. Crowdfunding is also highlighted by M1 and M4. M3 and M5 claim that all segments have potential and can grow in Malaysia. The results show that the respondents mentioned the banking sector, payment sector and crowdfunding which can grow in both countries. Moreover, some respondents think that in all segments Fintech has potential to grow in Malaysia.

The research firm Finextra with collaboration of dovetail completed a survey by more than 100 senior payments practitioners in 2017 . The respondents' organisations included payment processors, banks, corporate treasuries, merchant services, and industry associations. One of the conclusions of this survey is "Banks are convinced that payments will be fundamental to their future businesses, and confirm that payments transformation is critical to their digital programmes, but they are less confident in the clarity of their digital and payments transformation strategies" (Finextra \& dovetail, 2017).It is also witnessed that global non-cash transaction volumes grew 
Ali, Abdullah, \& Zaini | Fintech and Its Potential Impact on Islamic Banking and Finance Industry: A Case Study of Brunei Darussalam and Malaysia

11.2\% during 2014-2015 to reach 433.1 billion (Capgemini Worldwide \& BNP Paribas, 2017).

i. Fintech for Islamic finance industry an opportunity, and threat or disruptor

The resultsreveal that all the respondents from both Brunei Darussalam and Malaysia unanimously think that Fintech is an opportunity for IFI's. And B4 also opined that Fintech is also threat and disruptor for IFI's. M1 also added that awareness about Fintech is needed to get benefit from this opportunity. M3, M4, and M5 also mentioned that Fintech opens up many possibilities and reaches out to more consumers and cross border market.

These results clarify that all the respondents from Brunei and Malaysia are unanimously agreed on the point that Fintech is an opportunity for Islamic finance industry. These results are also in line with the results of previous surveys and studies. The report provided by (Accenture, 2016c)shows that banks are now recognizing that Fintech companies typically pose more of an opportunity than a threat. The same results are also found in a survey conducted by (Finextra \& dovetail, 2017).

j. Fintech Collaboration or Competition with Islamic Finance Industry

The resultsshow that three respondents from Brunei B1, B2 and B4 opined that collaboration between Fintech and IFI's is the right option as compare to the competition. B3 said it depends upon the situation means what the Fintech has new thing mean any innovative business model etc. Then we will decide for competition or collaboration.

The findings unveil that majority of the respondents from Malaysia M1, M4 and M5 opined that IFI's should collaborate with Fintech. M2 claims that banks are the biggest Fintechs (it means banks spend high percentage of revenue on IT), and Fintech does not create disruption it is only on-going evolution of financial services. M3 thinks that Fintech will definitely complement the Islamic financial services in Malaysia. From these results it is clear that majority of the respondents opined that collaboration with Fintech is preferable and suitable option for IFI's. According to a report provided by Capgemini Worldwide, a research and consultancy firm, as Fintechs are showing progress, traditional financial institutions have become more open to regard Fintechs as partners, rather than competitors. More than three-fourths $(76.7 \%)$ of executives agree Fintechs provide partnership opportunities. This partnership is good for both. Because traditional institutions pose advantages over non-traditional firms and customers favor and choose traditional firms due to trust, quality of service, security, and 
Ali, Abdullah, \& Zaini | Fintech and Its Potential Impact on Islamic Banking and Finance Industry: A Case Study of Brunei Darussalam and Malaysia

transparency, and they favor non-traditional firms in the areas of timely efficient service and better value for money (Capgemini Worldwide, 2017). According to another report provided by PwC (2016c), 42\% of banks are already engaging in joint partnerships with Fintech companies, this is more than any other financial sector. The report also claims that banks are also the most active of all sectors in holding venture funds to finance Fintech companies (19\%).Some of the respondents mentioned that the decision of collaboration and competition is depends upon the organization and what Fintech offers in that region. This trend of interoperability, coordination and collaboration is prevailing in the world (Duflos, 2015).P2P lenders Jimubox, RenRenDai and Minshengyidai and China Minsheng Bank are helping each other to manage and safeguard funds of investors (Ernst \& Young EY, 2016).The Dianrong.com and the regional Bank of Suzhou set up collaboration agreement in 2014 in targeting small enterprises (Finextra, 2014).There are numerous examples of this type can be found around the globe.

k. Strategy of Islamic Finance Industry Regarding Fintech

Fintech having aim to attract customers with services and products that are easy to use normally named as user friendly, speedy, efficient, automated and transparent(Mackenzie, 2015).

The results show that according to B2 and B4, IFIs should embrace Fintech and this is the right time for the adoption of Fintech as it is era of digitalization. But, B3 and B1 have different opinion that they are still at observing the situation and it's highly depends upon the organisation which strategy is good for them. Among Malaysian respondents, M1 thinks that IFI's should redefine the future in terms of rethinking, redesigning the products and services to meet the needs of millennial generation. M2 opined that IFI's should find solutions through Fintech. M3 claims that IFI's can get benefit of Fintech but they have to follow the shariah principles. M4 and M5 mentioned that IFI's have to follow regulations of Bank Negara Malaysia if they want to embrace Fintech.

The results show the Majority of the respondents opined that IFI's should embrace Fintech and find new solutions through Fintech. Some of the respondents explained IFI's should embrace Fintech, but they have to follow the shariah principles, and Malaysian respondents added that they have to also follow the regulations of Bank Negara Malaysia. In a survey conducted by (Capgemini Worldwide, 2017)it is highlighted that traditional firms are having and implementing a wide range of strategies in response to Fintech. Survey results shows that almost as many are developing their own in-house capabilities (59.2\%) as are seeking partnerships with Fintech (60.0\%). 
Ali, Abdullah, \& Zaini | Fintech and Its Potential Impact on Islamic Banking and Finance Industry: A Case Study of Brunei Darussalam and Malaysia

Secondly, investment in a Fintech is the next-most popular activity (38.0\%), though most institutions are stopping short of actually acquiring firms.

\section{Results of Content Analysis of Annual Reports of Malaysian Islamic Banks and Its Analysis}

To cope with the criteria of research sample and to compensate this research weakness, summative type of content analysis was adopted. For this, annual reports of 4 Islamic banks were selected among these 2 are fullfledged Islamic banks (M7, M8), and other 2 are Islamic subsidiaries of commercial banks (M6, M9). Annual reports of other commercial banks which have Islamic subsidiary but did not publish separate annual reports of their Islamic subsidiaries were excluded.

The results show that the coverage about Fintech in these reports is very low it's about $0.01 \%$. Only in one report which is of M7, the word Fintech is mentioned thirteen times but in remaining three reports it is only mentioned two times. This shows that M7 is more active in response to Fintech as compared to other Islamic banks. This is relevant and there are some evidences also support these results. Recently, M7 signed an agreement with a consulting firm "Cognizant" to make the foundation for its digital banking platform roll-out across its whole network (Peyton, 2017).

Table 2. Frequency and Coverage of word Fintech

\begin{tabular}{lcr}
\hline Name & $\begin{array}{c}\text { References/ } \\
\text { Frequency }\end{array}$ & Coverage \\
\hline M6 & 2 & $0.01 \%$ \\
M7 & 13 & $0.01 \%$ \\
M8 & 2 & $0.01 \%$ \\
M9 & 2 & $0.01 \%$ \\
\hline
\end{tabular}


Ali, Abdullah, \& Zaini | Fintech and Its Potential Impact on Islamic Banking and Finance Industry: A Case Study of Brunei Darussalam and Malaysia

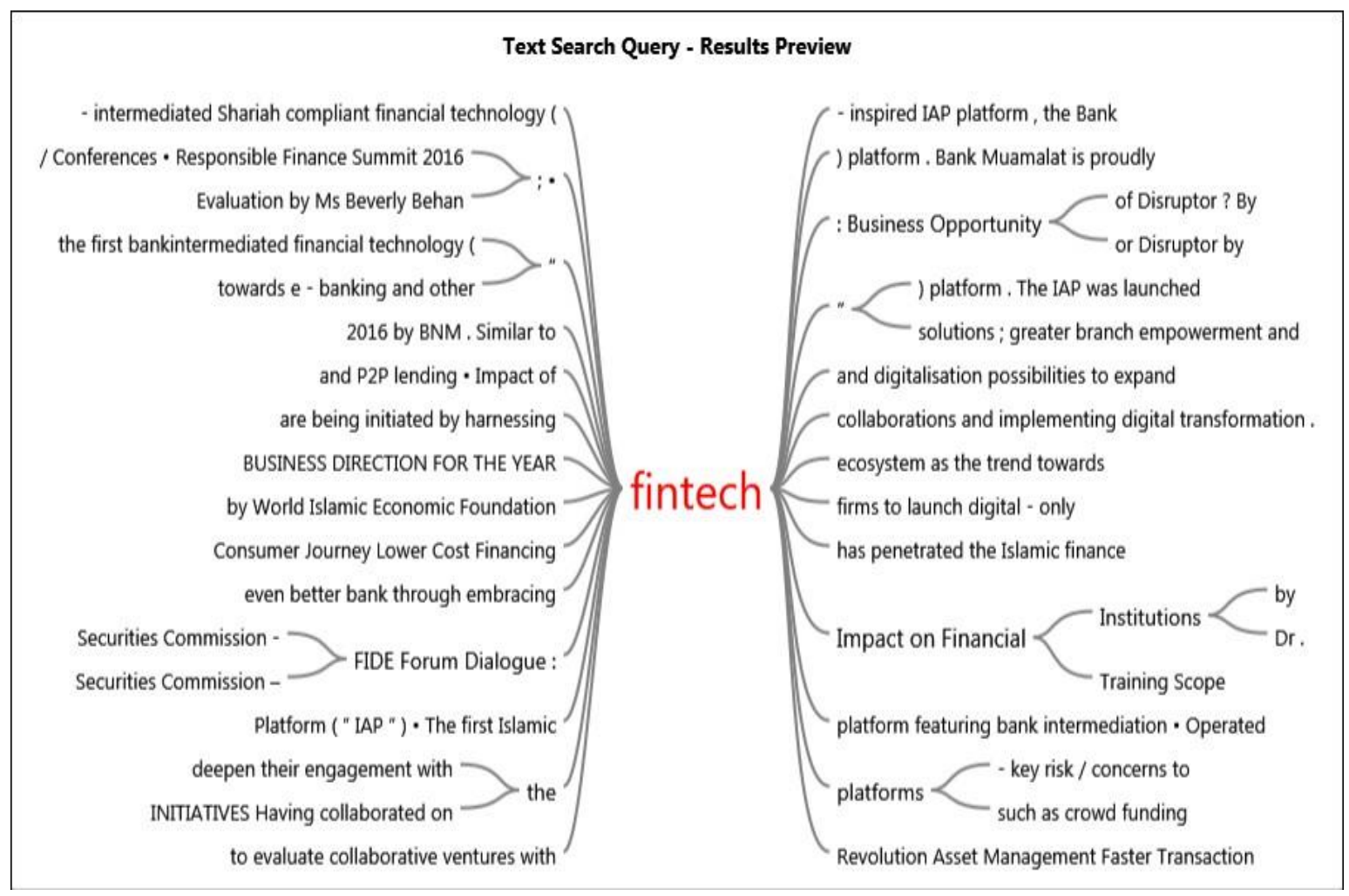

Figure 4. Text Search Query for Word Fintech

This text research query figure of these four reports shows that three out of these four banks (M9 is excluded) are the part of a platform which is Investment Account Platform. This is totally a digital platform which was established to expedite channeling of funds from investors to finance viable ventures. This is the first Islamic banks intermediated financial technology ("Fintech") platform was launched on 16 February 2016 (MIFC, 2016).

The NVivo output of this content analysis also clears that one common thing is mentioned in all these four reports that the representatives of these four Islamic banks attended a Fintech dialogue organized by Bank Negara Malaysia on 29 August 2016. The topic of that dialogue was: Fintech's Impact on Financial Institutions.

Only M7' annual report also shed light about different aspects of Fintech and it also highlights the views and strategy of this organization towards Fintech. The report shows that the authorities of this organization consider the Fintech an opportunity for Islamic finance industry and moreover, they also explained that "Fintechs that can help us improve our customer experience by being more efficient and differentiating ourselves from our competitors". They also prefer the option of partnership and collaboration with Fintech to keep the organization competitive in the market. The report also claims that by harnessing Fintech, organization have made a lot of saving. They used 
Ali, Abdullah, \& Zaini | Fintech and Its Potential Impact on Islamic Banking and Finance Industry: A Case Study of Brunei Darussalam and Malaysia

digital channels and mobile technology to offer services to millennials. Due to this they opened only one digital only banking branch instead of six branches as it was targeted earlier.

\section{Conclusion and Recommendations}

\section{Conclusions}

Clearly, Fintech has taken its prominent role in the finance sector, as Fintech has grown to be an important player in the sector and the added-value it provides cannot be denied hence Islamic Financial Institution in particular must response to this accordingly. The aim of this study is to explore the potential impact of Fintech on Islamic finance industry in Brunei Darussalam and Malaysia. The results clearly show that Fintech have great potential impact on both conventional and Islamic finance industry. This potential impact is in both ways i.e. positive and negative. Positive in the way that IFIs can harness and utilize the opportunities offers by digital shift and Fintech. IFIs can introduce new business models, can bring more transparency and efficiency in the products and can become able to provide the more customer friendly Islamic financial products and services. On the flip side, negative in a sense that if IFIs keep avoiding from embracing this phenomenon and completely neglecting this without adopting any appropriate strategy. In result, IFIs can lose their customers, and market share as well. And, the response and reaction of Islamic finance industry towards the emergence of Fintech and its potential impact seems very slow as compared to their conventional counterparts. This study has indicated important points which include the necessity for the Islamic financial institution to cope with the growth of Fintech. Fintech has become so dynamic yet prominent but yet Islamic Financial institution still shows some passivity in responding to the growth of Fintech despite realizing the potential impact Fintech may have upon the Islamic Financial Industry.In order to properly reap the benefits of Fintech, synergy between Islamic Financial Institutions and Fintech companies must be realized, both have its strength and weakness but through its collaboration, the weakness of each institution can be filled by the strength of others. It is timely for Islamic Financial institutions to be very proactive with the development of Fintech, the potential impact and disruption cannot be ignored.

\section{Recommendations}

There are following some recommendations for Islamic financial institutionsIFI's, regulators and also for academia especially for researcher in the area of Islamic finance.

IJIEF: International Journal of Islamic Economics and Finance, 2(1), 73-108 | 94 
Ali, Abdullah, \& Zaini | Fintech and Its Potential Impact on Islamic Banking and Finance Industry: A Case Study of Brunei Darussalam and Malaysia

Islamic finance industry in Brunei and Malaysia have to focus on the customer centricity and have to understand the behavior and needs of millennial generation of this digital era. They have to admit that the approach in which they are dealing the customers from last thirty to forty years, now, it has to be changed. This is also applicable in general Islamic finance industry as well.

IFls should start simplifying Islamic financial products and services to facilitate and assist comparisons between the market players and decrease client confusion. In the same time, it is important and crucial that IFIs have to design products with the user experience in mind instead of the normal "processes as design guidelines" approach.

IFls should start some test use cases of adopting technologies like blockchain, big data, artificial intelligence and robo advisors etc. Globally traditional financial firms are moving towards the adoption of these technologies with each passing year. So, this is indispensable for IFI's globally to show agility in this changing environment.

Keep in mind the risks and challenges which are the part of this digital era, like cyber security, data sharing, and scalability etc. IFIs should think holistically and have to tackle these challenges and manage these risks wisely and efficiently.

IFIs need the right people in place to drive digital transformation. The people who are able to bring the IT and business functions together will be helpful for IFIs to keep them competitive in the presence of Fintech.

RegTech has also become the part and parcel of Fintech. Regulators have to issue separate guidelines for Islamic finance industry and Islamic Fintech sector. Because normally they issued general guidelines for whole financial industry. This will remove the confusions and conflicts among scholars especially Islamic commercial law experts and Islamic finance industry as well.

There should be joint sitting and discussion of regulators, academia, Islamic finance industry and Fintech. So, they can make better and join plan to provide better, affordable Islamic financial products and services to the customers. And, this is necessary to solve the problems and cater the needs of customers. 
Ali, Abdullah, \& Zaini | Fintech and Its Potential Impact on Islamic Banking and Finance Industry:

A Case Study of Brunei Darussalam and Malaysia

\section{References}

Abdullah, O. (2017). Fintech for Islamic Finance. Retrieved January 25, 2018, from Fintech for Islamic Finance website: https://isImfintech.com/

Accenture. (2016a). Blockchain Technology. Retrieved from https://www.accenture.com/t20161019T015506_w__/usen/_acnmedia/PDF-35/Accenture-Blockchain-How-Banks-BuildingReal-Time-Global-Payment-Network.PDF

Accenture. (2016b). Fintech and the evolving landscape: landing points for the industry. Retrieved from https://www.finextra.com/finextradownloads/newsdocs/accenturefintech2016.pdf

Adam, M. F. (n.d.). Bitcoin: Shariah Compliant? Retrieved from http://darulfiqh.com/bitcoin-shariah-compliant/

Alonso, I. M. (2015). Crowdfunding in Islamic finance and microfinance: A case study of Egypt. Access to Finance and Human DevelopmentEssays on Zakah, Awqaf and Microfinance, 85.

Arslanian, H. (2016). 10 FinTech Predictions for Asia in 2017. Retrieved from https://letstalkpayments.com/10-fintech-predictions-for-asia-in2017/

Bergstra, J. A. (2015). Bitcoin and Islamic finance. Retrieved from https://dare.uva.nl/personal/pure/en/publications/bitcoin-andislamic-finance(fe22a3e7-d432-4067-a1be-1a40f34a26a1).html

Biancone, P. P., Secinaro, S., \& Kamal, M. (2019). Crowdfunding and Fintech: Business model sharia compliant. European Journal of Islamic Finance, (12).

Broby, D., \& Karkkainen, T. (2016). FINTECH in Scotland: building a digital future for the financial sector.

Capgemini. (2016). Payments Domain Top 10 Trends for 2016. Retrieved from https://www.capgemini.com/resources/payments-domain-top10-trends-for-2016

Capgemini Worldwide. (2017). Introducing The World FinTech Report 2017. Retrieved from https://www.capgemini.com/the-world-fintechreport-2017

Capgemini Worldwide, \& BNP Paribas. (2017). World Payments Report 2017 | Developments in the Global Payments Landscape. Retrieved from https://www.worldpaymentsreport.com/

CB Insights. (2018). Fintech Trends to Watch in 2018. Retrieved from /research/report/fintech-trends-2018/

CFA Institute. (2016). FINTECH SURVEY REPORT. Retrieved from https://www.cfainstitute.org/Survey/fintech_survey.PDF

Coraggio, G. (2017, January 5). P2P lending boosted by new Italian FinTech rules? Retrieved from http://www.gamingtechlaw.com/2017/01/p2p-lending-fintechitaly.html

Dhar, V., \& Stein, R. M. (2016). FinTech Platforms and Strategy. Retrieved from https://finopolis.ru/materials-offorum/2018/FinTech_Platforms.pdf

Dinarstandards. (2018). Islamic Fintech Report 2018. Retrieved from 
Ali, Abdullah, \& Zaini | Fintech and Its Potential Impact on Islamic Banking and Finance Industry:

A Case Study of Brunei Darussalam and Malaysia

https://www.dinarstandard.com/wp-

content/uploads/2018/12/Islamic-Fintech-Report-2018.pdf

Duflos, E. (2015, June 18). New accounts in China drive global financial inclusion figures [Text]. Retrieved October 2, 2017, from East Asia \& Pacific on the rise website:

http://blogs.worldbank.org/eastasiapacific/new-accounts-chinadrive-global-financial-inclusion-figures

Elo, S., \& Kyngäs, H. (2008). The qualitative content analysis process. Journal of Advanced Nursing, 62(1), 107-115.

Ernst \& Young EY. (2016). The rise of FinTech in China (p. 48). Retrieved from http://www.ey.com/Publication/vwLUAssets/ey-the-rise-of-fintechin-china/\$FILE/ey-the-rise-of-fintech-in-china.pdf

Evans, C. (2015). Bitcoin in Islamic Banking and Finance. Journal of Islamic Banking and Finance, 3(1), 1-11.

Financial Services Cloud Adoption: Top Concerns. (2017, January 3).

Retrieved January 22, 2018, from Peak 10 website:

http://www.peak10.com/financial-services-cloud-adoption-top-

concerns-making-move/

Finextra. (2014, October 13). Bank of Suzhou collaborates with

Dianrong.com on P2P loans platform. Retrieved October 2, 2017,

from Finextra Research website:

https://www.finextra.com/pressarticle/57122/bank-of-suzhou-

collaborates-with-dianrongcom-on-p2p-loans-platform

Finextra\, \& dovetail. (2017). Payments Transformation: Modernising to Stay Relevant in the Digital A. Retrieved from

https://www.finextra.com/surveys/survey.aspx?surveyguid=9d2938 cf-345f-43a5-9564-0f28c8398eb8

FINOCRACY, A. A., \& MIRAKHOR, A. (2017). Accelerating Risk Sharing Finance Via Fintech: Nextgen Islamic Finance. Retrieved from https://www.sid.ir/en/seminar/ViewPaper.aspx?FID=433e20170101

Hasan, S. B. M. (2017, December 28). Islamic Fintech - A Threat for Islamic Banks or an Opportunity? Retrieved January 25, 2018, from Ethis Crowd Blog website: https://www.ethiscrowd.com/blog/islamicfintech-and-islamic-banks/

International Data Corp. (IDC). (2012). Worldwide Big Data Technology and Services Forecast, 2012-16. Retrieved from http://www.idc.com/getdoc.jsp?containerld=25953

IOSCO. (2017). IOSCO Research Report on Financial Technologies (Fintech). Retrieved from https://www.iosco.org/library/pubdocs/pdf/IOSCOPD554.pdf

Islamic Financial Services Board IFSB. (2017). ISLAMIC FINANCIAL SERVICES INDUSTRY STABILITY REPORT 2017 (p. 158). Retrieved from Bank Negara Malaysia website: http://www.ifsb.org/docs/IFSB\%20IFSI\%20Stability\%20Report\%2020 17.pdf

Khan, T. (2015). Access to finance and human development-Essays on zakah, awqaf and microfinance: An introduction to the issues and papers. Access to Finance and Human Development-Essays on Zakah, Awqaf and Microfinance. 
Ali, Abdullah, \& Zaini | Fintech and Its Potential Impact on Islamic Banking and Finance Industry:

A Case Study of Brunei Darussalam and Malaysia

Kount. (2016). Mobile Payments \& Fraud: 2016 Report. Retrieved from http://info.kount.com/hubfs/Pdf_Files/2016_MobilePaymentsFraud Survey_Report.pdf

Kuo Chuen, D. L., Teo, E. G., \& others. (2015). Emergence of FinTech and the LASIC principles. Journal of Financial Perspectives, 3(3), 24-36.

KPMG. (2016). Robo advising: Hype or opportunity? Retrieved from https://home.kpmg.com/content/dam/kpmg/pdf/2016/07/RoboAdvising-Catching-Up-And-Getting-Ahead.pdf

Lacasse, R.-M., Lambert, B., \& Khan, N. (2017). Blockchain TechnologyArsenal for a Shariah-Compliant Financial Ecosystem. Retrieved from http://publications.uni.lu/bitstream/10993/33529/1/Research\%20P aper\%20Blockchain.pdf

LAJIS, S. M. (2017). RISK SHARING: OPTIMISING TRUE POTENTIAL OF ISLAMIC FINANCE.

Lajis, S. M. (2017). Risk-Sharing Securities: Accelerating Finance for SMEs. Islamic Economic Studies, 25(2), 35-55.

Laldin, M. A., \&Furqani, H. (2019). FinTech and Islamic Finance. Fintech in Islamic Finance: Theory and Practice.

Lim, S. J., \& Masih, M. (2017). Exploring portfolio diversification opportunities in Islamic capital markets through bitcoin: evidence from MGARCH-DCC and Wavelet approaches.

Lutfi, M. A., \& Ismail, M. A. (2016). Sadaqah-Based Crowdfunding Model For Microfinancing And Health Care. Retrieved from http://ddms.usim.edu.my/handle/123456789/14853

Mackenzie, A. (2015). The fintech revolution. London Business School Review, 26(3), 50-53.

Marzban, S., Asutay, M., \& Boseli, A. (2014). Shariah-compliant crowd funding: An efficient framework for entrepreneurship development in Islamic countries. Eleventh Harvard International Islamic Finance Form, Boston, April.

Mohamed, H. (2016). The Blockchain and Islamic Finance. Retrieved from https://www.academia.edu/30299556/The_Blockchain_and_Islamic _Finance

Mohamed, H. (2017, March). Smart Contracts in Islamic Economic Transactions - Wahed. Retrieved January 25, 2018, from https://journal.wahedinvest.com/smart-contracts-in-islamiceconomic-transactions/

Munshi, U. (2017). Islamic Fintech: Wake up to the Truth | LinkedIn. Retrieved January 25, 2018, from https://www.linkedin.com/pulse/islamic-fintech-wake-up-truthumar-munshi/

Ng, A., Mirakhor, A., \& Ibrahim, M. H. (2015). Risk Sharing and Crowdfunding. In Social Capital and Risk Sharing (pp. 115-131). Springer.

Nordin, N. S., Hassan, R., \& Nor, R. M. (2017). CRYPTOCURRENCY FROM SHARIAH PERSPECTIVE. Google Docs. Retrieved from https://drive.google.com/file/d/OB1d0lcOY3R9BcXJXVDBQSWM2Zjg/ view?usp=embed_facebook

Nurhisam, L. (2017). Bitcoin: Islamic Law Perspective. QIJIS (Qudus International Journal of Islamic Studies), 5(2), 85-100. 
Ali, Abdullah, \& Zaini | Fintech and Its Potential Impact on Islamic Banking and Finance Industry:

A Case Study of Brunei Darussalam and Malaysia

Patpatia \& Association and CGI. (2016). Beyond Robo-Advisors: Using Technology to Power New Methods of Client Advice and Interaction Patpatia \&amp; Associates, Inc. Retrieved from https://www.cgi.com/sites/default/files/robo-advisor-automatedadvice-platform-cgi-patpatia-white-paper.pdf

Peyton, A. (2017). Bank Islam plans digital Islamic banking roll-out. Retrieved January 26, 2018, from FinTech Futures website: http://www.bankingtech.com/2017/08/bank-islam-plans-digitalislamic-banking-roll-out/

PwC. (2016a). Blurred lines: How FinTech is shaping Financial Services.

Retrieved from https://www.pwc.de/de/newsletter/finanzdienstleistung/assets/insu rance-inside-ausgabe-4-maerz-2016.pdf

PwC. (2016b). Catching the FinTech wave: A survey on FinTech in Malaysia. Retrieved from https://www.pwc.com/my/en/publications/catchingthe-fintech-wave.html

PwC. (2016c). Customers in the spotlight: How FinTech is reshaping banking. Retrieved from https://www.pwc.com/gx/en/industries/financialservices/publications/fintech-is-reshaping-banking.html

PwC. (2017). Blockchain - The next wave of digitisation in asset management. Retrieved from https://www.pwc.com/gx/en/industries/financial-services/assetmanagement/publications/assets/pwc-2-revolution-or-evolution.pdf

Research and Markets. (2016a). Global Crowdfunding Market 2016-2020. Research and Markets. Retrieved from http://www.researchandmarkets.com/reports/3608989/globalcrowdfunding-market-2016-2020

Root, A. (2013). Shekra Blends Crowdfunding with Islamic Finance.". Retrieved from https://islamicmarkets.com/publications/crowdfunding-in-islamicfinance-and-microfinance-a-case-study

Schueffel, P. (2016). Taming the Beast: A Scientific Definition of Fintech. Journal of Innovation Management, 4(4), 32-54.

Taha, T., \& Macias, I. (2014). Crowdfunding and Islamic Finance: A Good Match? In Social Impact Finance (pp. 113-125). Springer.

Tayel, M. M. I., \& Sganga, C. (2015). CAN BITCOIN BE SELF-REGULATORY LEGAL TENDER?: A COMPARATIVE ANALYSIS OF UNITED STATES, EUROPEAN UNION AND ISLAMIC LEGAL SYSTEMS.

The White House. (2016). Big Data: A Report on Algorithmic Systems, Opportunity, and Civil Rights. Washington.

Torabi, O. (2017). Using reputation (fame) to reduce information asymmetry in Islamic risk-sharing crowdfunding models: a game theory approach.

Todorof, M. (2018). Shariah-compliant fintech in the banking industry. ERA Forum, 19, 1-17. Springer.

Turner, V., Gantz, J. F., Reinsel, D., \& Minton, S. (2014). The digital universe of opportunities: Rich data and the increasing value of the internet of things. IDC Analyze the Future, 5. 
Ali, Abdullah, \& Zaini | Fintech and Its Potential Impact on Islamic Banking and Finance Industry:

A Case Study of Brunei Darussalam and Malaysia

Veronika. (2016, December 21). Blockchain in Islamic Banking -

Opportunities Aplenty. Retrieved August 10, 2017, from The Fintech Times website: http://thefintechtimes.com/blockchain-islamicbanking-opportunities-aplenty/

Wahjono, S. I., \& Marina, A. (2017). Islamic crowdfunding: alternative funding solution. Editors, 30.

World Economic Forum. (2016). The future of financial infrastructure: An ambitious look at how blockchain can reshape financial services ( $p$. 130). Retrieved from http://weforum.org/reports/the-future-offinancial-infrastructure-an-ambitious-look-at-how-blockchain-canreshape-financial-services

Zubaidi, I. B., \& Abdullah, A. (2017). Developing a Digital Currency from an Islamic Perspective: Case of Blockchain Technology. International Business Research, 10(11), 79. 
Ali, Abdullah, \& Zaini | Fintech and Its Potential Impact on Islamic Banking and Finance Industry:

A Case Study of Brunei Darussalam and Malaysia

Appendix A

NVivo 11 Project Summary Report

Bruneian Respondents

Created on: 13-July-2018 4:45 PM

Created by: Ali

\begin{tabular}{|c|c|c|c|c|}
\hline Nodes & Sources & References & Created on & Created By \\
\hline Q1 Definition of Fintech & 4 & 5 & 30-Jan-18 4:30 PM & Ali \\
\hline $\begin{array}{l}\text { Automated Interactions } \\
\text { with customers }\end{array}$ & 1 & 1 & 30-Jan-18 4:28 PM & Ali \\
\hline $\begin{array}{l}\text { Combination of Finance } \\
\text { and Technology }\end{array}$ & 2 & 2 & 30-Jan-18 4:29 PM & Ali \\
\hline Fintech is a tool & 1 & 1 & 30-Jan-18 4:26 PM & Ali \\
\hline $\begin{array}{l}\text { Q2 Potential disruption areas } \\
\text { of Islamic banking and } \\
\text { finance industry due to } \\
\text { Fintech }\end{array}$ & 4 & 4 & 30-Jan-18 9:41 PM & Ali \\
\hline All segments may disrupt & 2 & 2 & 30-Jan-18 8:22 PM & Ali \\
\hline $\begin{array}{l}\text { Islamic finance industry is } \\
\text { very slow to respond } \\
\text { Fintech }\end{array}$ & 1 & 1 & 30-Jan-18 8:44 PM & Ali \\
\hline $\begin{array}{l}\text { Not disruption for any } \\
\text { segment }\end{array}$ & 1 & 1 & 30-Jan-18 8:06 PM & Ali \\
\hline $\begin{array}{l}\text { Q3 Fintech will take } \\
\text { customers from Islamic IFI's }\end{array}$ & 4 & 5 & 30-Jan-18 9:42 PM & Ali \\
\hline $\begin{array}{l}\text { Fintech will } \\
\text { customers from IFl's }\end{array}$ & 3 & 4 & 30-Jan-18 8:27 PM & Ali \\
\hline $\begin{array}{lr}\text { If IFI's keep away from } \\
\text { embracing } & \text { Fintech or } \\
\text { innovative } & \text { business } \\
\text { models } & \text { and } \\
\text { technological } & \\
\text { adaptation } & \end{array}$ & 2 & 2 & 30-Jan-18 8:45 PM & Ali \\
\hline $\begin{array}{l}\text { No, Fintech will not take } \\
\text { customers from IFI's }\end{array}$ & 1 & 1 & 30-Jan-18 8:04 PM & Ali \\
\hline $\begin{array}{l}\text { Q4 Potential of Blockchain } \\
\text { and Smart contracts in } \\
\text { Islamic finance industry }\end{array}$ & 4 & 5 & 30-Jan-18 4:37 PM & Ali \\
\hline No, I don't believe & 1 & 1 & 30-Jan-18 8:03 PM & Ali \\
\hline $\begin{array}{l}\text { Yes, these technologies } \\
\text { have big potential }\end{array}$ & 3 & 4 & 30-Jan-18 8:45 PM & Ali \\
\hline $\begin{array}{l}\text { Challenge of shariah } \\
\text { compliance }\end{array}$ & 1 & 1 & 30-Jan-18 8:35 PM & Ali \\
\hline $\begin{array}{l}\text { Q5 Potential of Artificial } \\
\text { Intelligence, Big data, IoT and } \\
\text { Robo advisors in Islamic } \\
\text { finance industry }\end{array}$ & 4 & 6 & 30-Jan-18 4:41 PM & Ali \\
\hline No, I don't believe & 2 & 2 & 30-Jan-18 4:43 PM & Ali \\
\hline $\begin{array}{l}\text { Yes, these technologies } \\
\text { have big potential }\end{array}$ & 2 & 2 & 30-Jan-18 8:48 PM & Ali \\
\hline $\begin{array}{l}\text { Challenge of shariah } \\
\text { compliance }\end{array}$ & 4 & 4 & 30-Jan-18 8:47 PM & Ali \\
\hline
\end{tabular}

IJIEF: International Journal of Islamic Economics and Finance, 2(1), 73-108 | 101 
Ali, Abdullah, \& Zaini | Fintech and Its Potential Impact on Islamic Banking and Finance Industry:

A Case Study of Brunei Darussalam and Malaysia

\begin{tabular}{|c|c|c|c|c|}
\hline $\begin{array}{l}\text { Risk of data sharing and } \\
\text { privacy theft in the } \\
\text { usage of big data }\end{array}$ & 3 & 3 & 30-Jan-18 4:51 PM & Ali \\
\hline $\begin{array}{l}\text { Q6 Cloud computing } \\
\text { adoption }\end{array}$ & 4 & 8 & 30-Jan-18 5:18 PM & Ali \\
\hline $\begin{array}{l}\text { Depends upon the } \\
\text { organization's policy and } \\
\text { resources }\end{array}$ & 2 & 2 & 30-Jan-18 8:38 PM & Ali \\
\hline Risk and challenges & 3 & 3 & 30-Jan-18 8:48 PM & Ali \\
\hline Cyber security & 1 & 1 & 30-Jan-18 4:54 PM & Ali \\
\hline Legacy system of banks & 1 & 1 & 30-Jan-18 8:15 PM & Ali \\
\hline Scalability & 1 & 1 & 30-Jan-18 9:27 PM & Ali \\
\hline $\begin{array}{l}\text { Yes, cloud computing } \\
\text { adoption is good option }\end{array}$ & 3 & 3 & 30-Jan-18 4:57 PM & Ali \\
\hline $\begin{array}{l}\text { Q7 Financial inclusion } \\
\text { through Fintech }\end{array}$ & 4 & 5 & 30-Jan-18 9:28 PM & Ali \\
\hline $\begin{array}{l}\text { Mobile technology can } \\
\text { help a lot for financial } \\
\text { inclusion }\end{array}$ & 1 & 1 & 30-Jan-18 5:10 PM & Ali \\
\hline $\begin{array}{l}\text { Yes, IFI's can promote } \\
\text { financial inclusion through } \\
\text { Fintech }\end{array}$ & 4 & 4 & 30-Jan-18 8:40 PM & Ali \\
\hline $\begin{array}{l}\text { Q8 Fintech segments which } \\
\text { can grow in Brunei }\end{array}$ & 4 & 5 & 30-Jan-18 5:00 PM & Ali \\
\hline Banking services providers & 2 & 2 & 30-Jan-18 8:50 PM & Ali \\
\hline Not clear & 1 & 1 & 30-Jan-18 8:13 PM & Ali \\
\hline Payments & 2 & 2 & 30-Jan-18 8:39 PM & Ali \\
\hline $\begin{array}{l}\text { Q9 Fintech for Islamic } \\
\text { finance industry is } \\
\text { opportunity, threat or } \\
\text { disruptor }\end{array}$ & 4 & 6 & 30-Jan-18 8:48 PM & Ali \\
\hline All three & 2 & 2 & 30-Jan-18 8:47 PM & Ali \\
\hline Opportunity & 3 & 4 & 30-Jan-18 4:45 PM & Ali \\
\hline $\begin{array}{l}\text { We can bring speed } \\
\text { and efficiency in our } \\
\text { operations through } \\
\text { Fintech }\end{array}$ & 2 & 2 & 30-Jan-18 8:49 PM & Ali \\
\hline $\begin{array}{l}\text { Q } 10 \text { IFI's should collaborate } \\
\text { or compete with Fintech }\end{array}$ & 4 & 4 & 30-Jan-18 5:01 PM & Ali \\
\hline $\begin{array}{l}\text { Collaboration is the right } \\
\text { option }\end{array}$ & 3 & 3 & 30-Jan-18 9:30 PM & Ali \\
\hline $\begin{array}{l}\text { It depends upon the } \\
\text { situation }\end{array}$ & 1 & 1 & 30-Jan-18 8:41 PM & Ali \\
\hline $\begin{array}{l}\text { Q11 Strategy should be } \\
\text { adopted by IFI's for Fintech }\end{array}$ & 4 & 5 & 30-Jan-18 10:28 PM & Ali \\
\hline $\begin{array}{l}\text { IFI's should embrace } \\
\text { Fintech }\end{array}$ & 2 & 2 & 30-Jan-18 9:30 PM & Ali \\
\hline $\begin{array}{l}\text { We are still working on it } \\
\text { and it depends upon the } \\
\text { organization }\end{array}$ & 3 & 3 & 30-Jan-18 8:43 PM & Ali \\
\hline
\end{tabular}

IJIEF: International Journal of Islamic Economics and Finance, 2(1), 73-108 | 102 
Ali, Abdullah, \& Zaini | Fintech and Its Potential Impact on Islamic Banking and Finance Industry: A Case Study of Brunei Darussalam and Malaysia

NVivo 11 Source Summary Report (Bruneian Respondents)

Created on: 14- July- 2018 12:20 PM

Created By: Ali

\begin{tabular}{lll}
\hline Items & Numbers & Created by \\
\hline No of Source & 5 & Ali \\
\hline No of total Nodes & 45 & Ali \\
\hline No of Anchor Nodes & 11 & Ali \\
\hline No of Child Nodes & 34 & Ali \\
\hline No of Memos & 0 & Ali \\
\hline No of Cases & 0 & Ali \\
\hline No of project maps & 11 & Ali \\
\hline
\end{tabular}


Ali, Abdullah, \& Zaini | Fintech and Its Potential Impact on Islamic Banking and Finance Industry:

A Case Study of Brunei Darussalam and Malaysia

Appendix B

\section{NVivo 11 Project Summary Report}

\section{Malaysian Respondents}

Created on: 1-July-18 4:03 AM

Created By: Ali

\begin{tabular}{|c|c|c|c|c|}
\hline Node Item & Sources & References & Created on & Created By \\
\hline Q1 Definition of Fintech & 5 & 4 & 01-Feb-18 7:30 PM & Ali \\
\hline $\begin{array}{l}\text { Emerging Financial Services } \\
\text { Sector with the } \\
\text { deployment of technology }\end{array}$ & 2 & 2 & 01-Jan-18 7:31 PM & Ali \\
\hline $\begin{array}{l}\text { Usage of technology that } \\
\text { gives customers access to } \\
\text { banking }\end{array}$ & 1 & 1 & 01-Feb-18 7:29 PM & Ali \\
\hline $\begin{array}{l}\text { Redefining of banking and } \\
\text { takaful }\end{array}$ & 1 & 1 & 01-Feb-18 7:27 PM & Ali \\
\hline $\begin{array}{l}\text { Q2 Potential disruption areas } \\
\text { of Islamic banking and finance } \\
\text { industry due to Fintech }\end{array}$ & 5 & 5 & 01-Feb-18 8:29 PM & Ali \\
\hline $\begin{array}{l}\text { Islamic Banks and Takaful } \\
\text { Companies are still } \\
\text { exploring Fintech }\end{array}$ & 2 & 2 & 01-Feb-18 8:31 PM & Ali \\
\hline $\begin{array}{l}\text { Due to Fintech there is } \\
\text { need to re-assess } \\
\text { traditional way of } \\
\text { conducting business and } \\
\text { re-engineering of } \\
\text { innovative offers for } \\
\text { customers }\end{array}$ & 3 & 3 & 01-Feb-18 8:35 PM & Ali \\
\hline $\begin{array}{l}\text { Q3 Fintech will take } \\
\text { customers from Islamic IFI's }\end{array}$ & 5 & 9 & 01-Feb-18 8:26 PM & Ali \\
\hline $\begin{array}{l}\text { Yes, Fintech will take } \\
\text { customers from IFl's }\end{array}$ & 4 & 7 & 01-Feb-18 8:40 PM & Ali \\
\hline $\begin{array}{l}\text { Fintech organizations } \\
\text { have yet to fully } \\
\text { appreciate the impact of } \\
\text { risk (leading to losses). } \\
\text { Security (cyberattacks } \\
\text { and fraudulent attacks) } \\
\text { and regulatory costs } \\
\text { (AML, KYC, Reporting } \\
\text { etc.) }\end{array}$ & 1 & 1 & 01-Feb-18 8:43 PM & Ali \\
\hline $\begin{array}{l}\text { Fintech innovations are } \\
\text { in line with the digital } \\
\text { shift }\end{array}$ & 1 & 1 & 01-Feb-18 8:44 PM & Ali \\
\hline $\begin{array}{l}\text { If IFI's will not fulfil the } \\
\text { needs of millennial } \\
\text { generation }\end{array}$ & 1 & 1 & & Ali \\
\hline $\begin{array}{l}\text { No, I don't agree on taking } \\
\text { customers from IFl's but do } \\
\text { agree on Fintech } \\
\text { innovations }\end{array}$ & 1 & 2 & 01-Feb-18 8:48 PM & Ali \\
\hline IFI's should embrace & 1 & 1 & 01-Feb-18 8:49 PM & Ali \\
\hline
\end{tabular}

IJIEF: International Journal of Islamic Economics and Finance, 2(1), 73-108 | 104 
Ali, Abdullah, \& Zaini | Fintech and Its Potential Impact on Islamic Banking and Finance Industry:

A Case Study of Brunei Darussalam and Malaysia

\begin{tabular}{|c|c|c|c|c|}
\hline $\begin{array}{c}\text { technological } \\
\text { transformation on } \\
\text { leveraging side }\end{array}$ & & & & \\
\hline $\begin{array}{l}\text { Q4 Potential of Blockchain } \\
\text { and Smart contracts in Islamic } \\
\text { finance industry }\end{array}$ & 5 & 7 & 01-Feb-18 8:30 PM & Ali \\
\hline $\begin{array}{l}\text { Smart contracts have big } \\
\text { potential in Islamic finance }\end{array}$ & 1 & 1 & 01-Feb-18 8:52 PM & Ali \\
\hline $\begin{array}{l}\text { In, Malaysia we have not } \\
\text { seen any adoption of } \\
\text { Blockchain from IFI's }\end{array}$ & 2 & 2 & 01-Feb-18 8:55 PM & Ali \\
\hline $\begin{array}{l}\text { Blockchain is good in } \\
\text { recording transactions } \\
\text { hence facilitating more } \\
\text { secure online transactions }\end{array}$ & 1 & 1 & 01-Feb-18 8:57 PM & Ali \\
\hline $\begin{array}{l}\text { Further Control (Laws and } \\
\text { regulations) and in-depth } \\
\text { studies needed to be } \\
\text { conducted to understand } \\
\text { potential opportunities }\end{array}$ & 1 & 3 & 01-Feb-18 9:00 PM & Ali \\
\hline $\begin{array}{l}\text { Q5 Potential of Artificial } \\
\text { Intelligence, Big data, loT and } \\
\text { Robo advisors in Islamic } \\
\text { finance industry }\end{array}$ & 5 & 8 & 01-Feb-18:35 PM & Ali \\
\hline $\begin{array}{l}\text { Yes, these technologies } \\
\text { have potential in Islamic } \\
\text { finance }\end{array}$ & 4 & 7 & 01-Feb-18 9:05 PM & Ali \\
\hline $\begin{array}{l}\text { Al and robo advisors for } \\
\text { instance have room in } \\
\text { Islamic finance industry }\end{array}$ & 1 & 1 & 01-Feb-18 9:08 PM & Ali \\
\hline $\begin{array}{l}\text { Chat bots can improve } \\
\text { customers' experience }\end{array}$ & 1 & 1 & 01-Feb-18 9:13 PM & Ali \\
\hline $\begin{array}{l}\text { At the end we will use } \\
\text { these technologies }\end{array}$ & 1 & 1 & 01-Feb-18 9:20 PM & Ali \\
\hline $\begin{array}{l}\text { We are thinking about } \\
\text { these technologies }\end{array}$ & 1 & 1 & 01-Feb-18 9:25 PM & Ali \\
\hline Q6 Cloud computing adoption & 5 & 6 & 02-Feb-18 4:27 PM & Ali \\
\hline $\begin{array}{l}\text { Yes, by adopting cloud } \\
\text { computing IFI's can reduce } \\
\text { their IT costs }\end{array}$ & 3 & 3 & 02-Feb-18 4:30 PM & Ali \\
\hline $\begin{array}{l}\text { Data Security, } \\
\text { attacks and risks also } \\
\text { involved }\end{array}$ & 3 & 3 & 02-Feb-18 4:38 PM & Ali \\
\hline $\begin{array}{l}\text { Q7 Financial inclusion through } \\
\text { Fintech }\end{array}$ & 5 & 7 & 02-Feb-18 4:47 PM & Ali \\
\hline $\begin{array}{l}\text { Yes, IFI's can promote } \\
\text { financial inclusion through } \\
\text { Fintech }\end{array}$ & 5 & 7 & 02-Feb-18 5:10 PM & Ali \\
\hline $\begin{array}{l}\text { Fintech Provide } \\
\text { solutions but it would } \\
\text { not solve the underlying } \\
\text { cause of the problem }\end{array}$ & 1 & 1 & 02-Feb-18 5:17 PM & Ali \\
\hline $\begin{array}{l}\text { Fintech has allowed this } \\
\text { by providing innovative }\end{array}$ & 2 & 2 & 02-Feb-18 5:23 PM & Ali \\
\hline
\end{tabular}

IJIEF: International Journal of Islamic Economics and Finance, 2(1), 73-108 | 105 
Ali, Abdullah, \& Zaini | Fintech and Its Potential Impact on Islamic Banking and Finance Industry: A Case Study of Brunei Darussalam and Malaysia

\begin{tabular}{|c|c|c|c|c|}
\hline $\begin{array}{l}\text { solutions as a new touch } \\
\text { point for customers }\end{array}$ & & & & \\
\hline $\begin{array}{l}\text { Q8 Fintech segments which } \\
\text { can grow in Brunei }\end{array}$ & 5 & 8 & 02-Feb-18 9:40 PM & Ali \\
\hline InsureTech & 1 & 1 & 02-Feb-18 9:50 PM & Ali \\
\hline Crowdfunding & 2 & 2 & 02-Feb-18 9:53 PM & Ali \\
\hline Payments & 3 & 3 & 02-Feb-18 9:59 PM & $\overline{A l i}$ \\
\hline $\begin{array}{l}\text { All segments have } \\
\text { potential and can grow in } \\
\text { Malaysia }\end{array}$ & 2 & 2 & $\begin{array}{l}\text { 02-Feb-18 10:04 } \\
\text { PM }\end{array}$ & Ali \\
\hline $\begin{array}{l}\text { Q9 Fintech for Islamic finance } \\
\text { industry is opportunity, threat } \\
\text { or disruptor }\end{array}$ & 5 & 8 & $\begin{array}{l}\text { 02-Feb-18 10:09 } \\
\text { PM }\end{array}$ & Ali \\
\hline It's all three & 1 & 1 & $\begin{array}{l}\text { 02-Feb-18 10:17 } \\
\text { PM }\end{array}$ & Ali \\
\hline Opportunity & 4 & 7 & $\begin{array}{ll}\text { 02-Feb-18 } & 10: 23 \\
\text { PM } & \end{array}$ & Ali \\
\hline $\begin{array}{l}\text { To avail the opportunity } \\
\text { awareness is needed }\end{array}$ & 1 & 1 & $\begin{array}{ll}\text { 02-Feb-18 } & 10: 31 \\
\text { PM } & \end{array}$ & Ali \\
\hline $\begin{array}{l}\text { Fintech open up many } \\
\text { possibilities and reach } \\
\text { out many consumers } \\
\text { across markets and } \\
\text { cross borders }\end{array}$ & 2 & 2 & $\begin{array}{l}\text { 02-Feb-18 } \\
\text { PM }\end{array}$ & Ali \\
\hline $\begin{array}{l}\text { Q } 10 \text { IFI's should collaborate } \\
\text { or compete with Fintech }\end{array}$ & 5 & 5 & $\begin{array}{ll}02-F e b-18 & 10: 42 \\
\text { PM } & \end{array}$ & Ali \\
\hline IFI's should collaborate & 3 & 3 & $\begin{array}{ll}\text { 01-Feb-18 } & 10: 48 \\
\text { PM } & \end{array}$ & Ali \\
\hline $\begin{array}{l}\text { No disruption, banks are } \\
\text { itself biggest Fintechs. This } \\
\text { is only an ongoing } \\
\text { evolution of financial } \\
\text { services }\end{array}$ & 1 & 1 & $\begin{array}{l}\text { 01-Feb-18 } \\
\text { PM }\end{array}$ & Ali \\
\hline $\begin{array}{l}\text { Fintech will definitely } \\
\text { complement Islamic } \\
\text { finance industry in } \\
\text { Malaysia }\end{array}$ & 1 & 1 & $\begin{array}{l}\text { 02-Feb-18 } \\
\text { PM }\end{array}$ & Ali \\
\hline $\begin{array}{l}\text { Q11 Strategy should be } \\
\text { adopted by IFI's for Fintech }\end{array}$ & 5 & 5 & 02-Feb-18 11:00PM & Ali \\
\hline Redefining the future & 1 & 1 & $\begin{array}{ll}\text { 02-Feb-18 11:07 } \\
\text { PM }\end{array}$ & Ali \\
\hline $\begin{array}{l}\text { Find solutions through } \\
\text { Fintech }\end{array}$ & 1 & 1 & $\begin{array}{l}\text { 02-Feb-18 11:11 } \\
\text { PM }\end{array}$ & Ali \\
\hline $\begin{array}{l}\text { IFl's can take benefit of } \\
\text { Fintech but they should } \\
\text { follow the shariah } \\
\text { principles }\end{array}$ & 1 & 1 & $\begin{array}{l}\text { 02-Feb-18 } \\
\text { PM }\end{array}$ & Ali \\
\hline $\begin{array}{l}\text { IFI's in Malaysia have to } \\
\text { follow regulations of BNM } \\
\text { while embracing Fintech }\end{array}$ & 2 & 2 & $\begin{array}{l}\text { 02-Feb-18 11:25 } \\
\text { PM }\end{array}$ & Ali \\
\hline
\end{tabular}

IJIEF: International Journal of Islamic Economics and Finance, 2(1), 73-108 | 106 
Ali, Abdullah, \& Zaini | Fintech and Its Potential Impact on Islamic Banking and Finance Industry: A Case Study of Brunei Darussalam and Malaysia

\section{NVivo 11 Source Summary Report (Malaysian Respondents)}

Created on: 14-July-2018 11:15 AM

Created By: Ali

\begin{tabular}{lll}
\hline Items & Numbers & Created by \\
\hline No of total Nodes & 51 & Ali \\
\hline No of Anchor Nodes & 11 & Ali \\
\hline No of Child Nodes & 40 & Ali \\
\hline No of Memos & 0 & Ali \\
\hline No of Cases & 0 & Ali \\
\hline No of project maps & 11 & Ali \\
\hline
\end{tabular}


Ali, Abdullah, \& Zaini | Fintech and Its Potential Impact on Islamic Banking and Finance Industry: A Case Study of Brunei Darussalam and Malaysia

This page is intentionally left blank

IJIEF: International Journal of Islamic Economics and Finance, 2(1), 73-108 | 108 